\title{
The morphological variation within Westringia fruticosa (Labiatae) from eastern Australia and Lord Howe Island
}

\author{
Barry J. Conn and Merrin E. Tozer
}

\begin{abstract}
Conn, Barry J. and Tozer, Merrin E. (National Herbarium of New South Wales, Royal Botanic Gardens, Mrs Macquaries Road, Sydney, NSW, Australia 2000). The morphological variation within Westringia fruticosa (Labiatae) from eastern Australia and Lord Howe Island. 1993. Telopea 5(2): 341-350. An evaluation of the morphological variation within Westringia fruticosa of eastern Australia and Lord Howe Island revealed two distinct species (viz. W. fruticosa and the new species W. viminalis). Westringia viminalis is described for the first time. This species is endemic to Lord Howe Island, whereas Westringia fruticosa is restricted to mainland Australia.
\end{abstract}

\section{Introduction}

Seemingly subtle, although significant, characters that separate the Lord Howe Island Westringia from the Australian mainland populations of $W$. fruticosa have been overlooked by previous workers. As previously alluded to by Bentham (1870), the delimitation of taxa within Westringia has proved difficult because of the apparent lack of 'any tangible characters' (Bentham 1870: 127). Furthermore, very few Lord Howe Island collections were available to Dr Bernard Boivin when he reviewed the genus (Boivin 1949). Accounts of the vegetation of Lord Howe Island (Oliver 1916; Pickard 1983; Rodd 1974; Rodd \& Pickard 1983) have regarded the Westringia of the island as conspecific with W. fruticosa of mainland Australia. During the preparation of an account of the floras of Lord Howe Island and Norfolk Island by Mr Peter Green (Royal Botanic Gardens, Kew), the identity of the Lord Howe Island populations of Westringia was questioned.

Our initial observations suggested that the Lord Howe Island material of this group was probably distinct from the mainland Australian specimens, but it was difficult to clearly circumscribe the characteristics of each group. The situation was further complicated because there appeared to be morphological variation between and within mainland populations. Westringia fruticosa is restricted to coastal regions of New South Wales and extends discontinuously from northern regions to southern parts of the State (Figure 1a). On Lord Howe Island the populations (here recognised as the new species $W$. viminalis) are mainly confined to the southern mountainous regions of the island (Figure 1b).

A detailed multivariate morphometric analysis of Westringia fruticosa was initiated to determine: (1) the distinctness of the Lord Howe Island populations from those of mainland Australia, and (2) the amount and pattern of variation amongst the Australian mainland populations. 


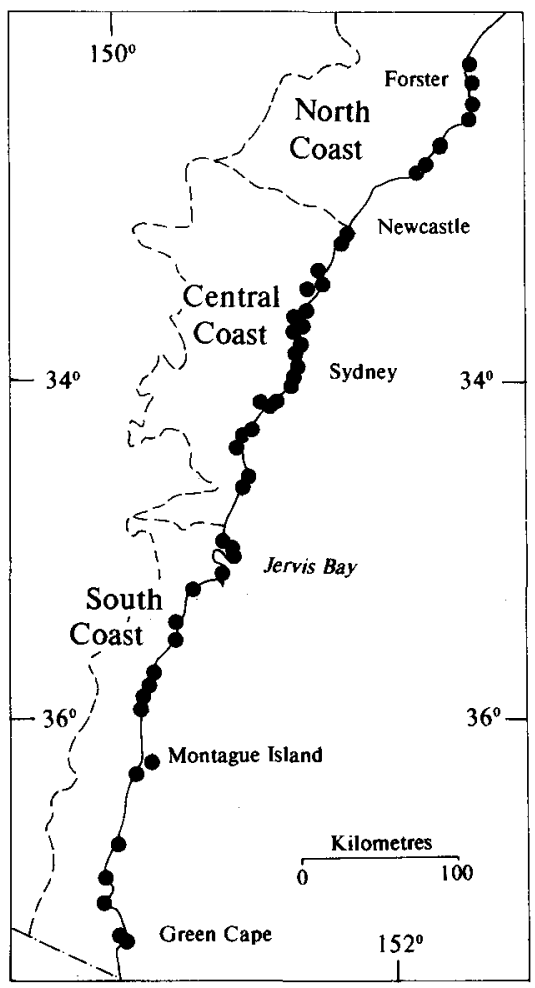

a

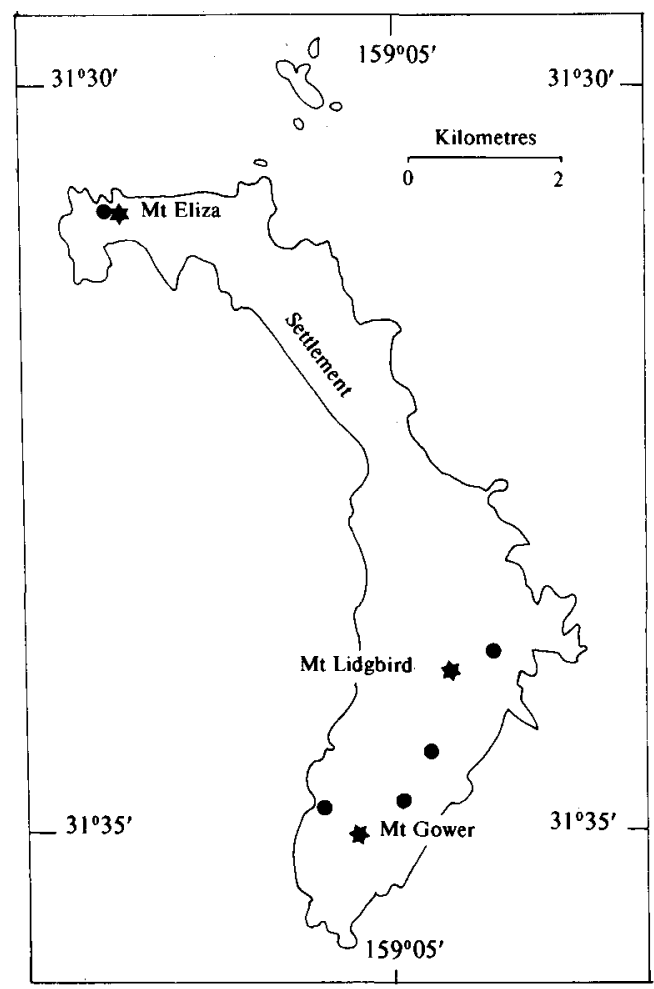

b

Figure 1. a, distribution of Westringia fruticosa, with coastal divisions of New South Wales; b, distribution of Westringia viminalis on Lord Howe Island.

\section{Methods and presentation}

These investigations have been based on population studies and on herbarium material as held at MEL and NSW (abbreviations as designated in Holmgren et al. 1990). Forty-one collections were used for the numerical analyses (cited in Appendix 1), all of these are held at NSW. Thirty specimens representing 10 populations from throughout the distributional range of the group were collected by the authors (as cited in Appendix 1). Two to five specimens were examined for each population. Selected existing herbarium collections were also included in the analyses.

\section{Characters}

Although it proved difficult to identify useful taxonomic characters, seven morphometric variables were chosen (as listed below).
1. Habit
5. Prophyll length $(\mathrm{mm})$
2. Leaf width (mm)
6. Calyx lobe length $(\mathrm{mm})$
3. Leaf length to width ratio
7. Calyx tube length (mm)
4. Leaf hair length $(\mathrm{mm})$ 
Character 1 (Habit) is a 2-state variable. All other characters (characters 2-7) were absolute measurements (averaged) on a continuous scale. It is assumed that most of the characters used are self-explanatory; however, two require further comment.

Habit: this character was scored as either (1) weakly branched or (0) strongly branched. The weakly branched shrubs have a very open branching architecture such that the branches of the plants are usually supported by the surrounding vegetation. The strongly branched state is characteristic of densely branching shrubs. These branches are self-supporting even when the plants are growing in open areas.

Prophyll length: the apical region of the prophyll is readily damaged and is caducous. The prophylls of dried herbarium material are particularly likely to be damaged. Therefore, the measurements of prophyll length are best regarded as minimal lengths only (particularly for the Lord Howe Island material).

Other characters that were also considered but not used in the analysis include internode length, leaf colour, and density of the indumentum. Internode length and leaf colour appeared to be affected by microclimatic differences within sites on Lord Howe Island and the mainland. Leaf colour was also difficult to quantify. Initially the taxonomic value of the leaf hair density was not considered because both taxa superficially appeared to be equally densely hairy. After the analysis of the other morphological characters was completed, an SEM survey of the leaves revealed a difference in the density of hairs between the two taxa. The hair density values were estimated from the SEM images.

\section{Data analysis}

Analyses were carried out using the PATN pattern analysis package (Belbin 1987, 1989). The data were standardised by range. Manhattan metric distance or Gower metric association measures between individual collections were submitted to ordination and clustering techniques to assist in the interpretation of morphological patterns within the data. Ordination by Multidimensional Scaling (MDS) was used in this study. The linear correlation between each of the morphological characters and the axes in the MDS ordination space were investigated using the principal axis correlation program (PCC). Correlation coefficients ( $r$ ) were calculated for each character and these quantified the significance of the association. The direction of the correlation indicated the usefulness of the characters to differentiate the Lord Howe Island populations from those of mainland Australia. Clustering of the morphometric data, by use of the fusion criterion of unweighted pair-group method using arithmetic averages (UPGMA), was carried out for comparison with the ordination results. Cramer association values $(V)$ were calculated for each of the characters. As for the correlation coefficients, the cramer values also quantified the usefulness of each character. The rationale for the use of these multivariate techniques is provided by Belbin (1987, 1989).

\section{Results}

The scatter diagram of the nonmetric MDS ordination in two dimensions, with the overall stress reduced to 0.147 , is presented in Figure 2. The MDS analysis provides a useful simplification of the data with two groups discernible. The Lord Howe Island populations form one cluster that is distinct from the mainland Australian populations (Figure 2). The cluster analysis of the specimens (Figure 3 - simplified by truncation at the six-group level) shows that there is a clear distinction between the Lord Howe Island collections and the mainland material. 
Further investigations into the morphological variation within the mainland Australian specimens, using clustering and ordination analyses as described above, were unable to detect any significant pattern of variation among the populations. Although these results are not presented here, the lack of meaningful clustering within and between the mainland populations is indicated in Figure 2. It was found that the within-population variation was often as great or even greater than found between populations.

\section{Taxonomic conclusion and circumscription}

The Lord Howe Island collections (Figure 2) of the W. fruticosa group can be distinguished from those of mainland Australia. It is concluded that the former are sufficiently distinct to be recognised as a species ( $W$. viminalis) separate from $W$. fruticosa s. str. Westringia fruticosa (mainland Australian collections only; Figure 1a) are strongly branched and usually upright shrubs (habit variable: $\mathrm{r}=0.962 ; V=1$ ), whereas $W$. viminalis is a weakly branched shrub with a very open branching architecture. Increased exposure to the salt-laden winds of the rocky headlands, and subsequent desiccation, frequently reduces $W$. fruticosa to a stunted or semi-prostrate shrub.

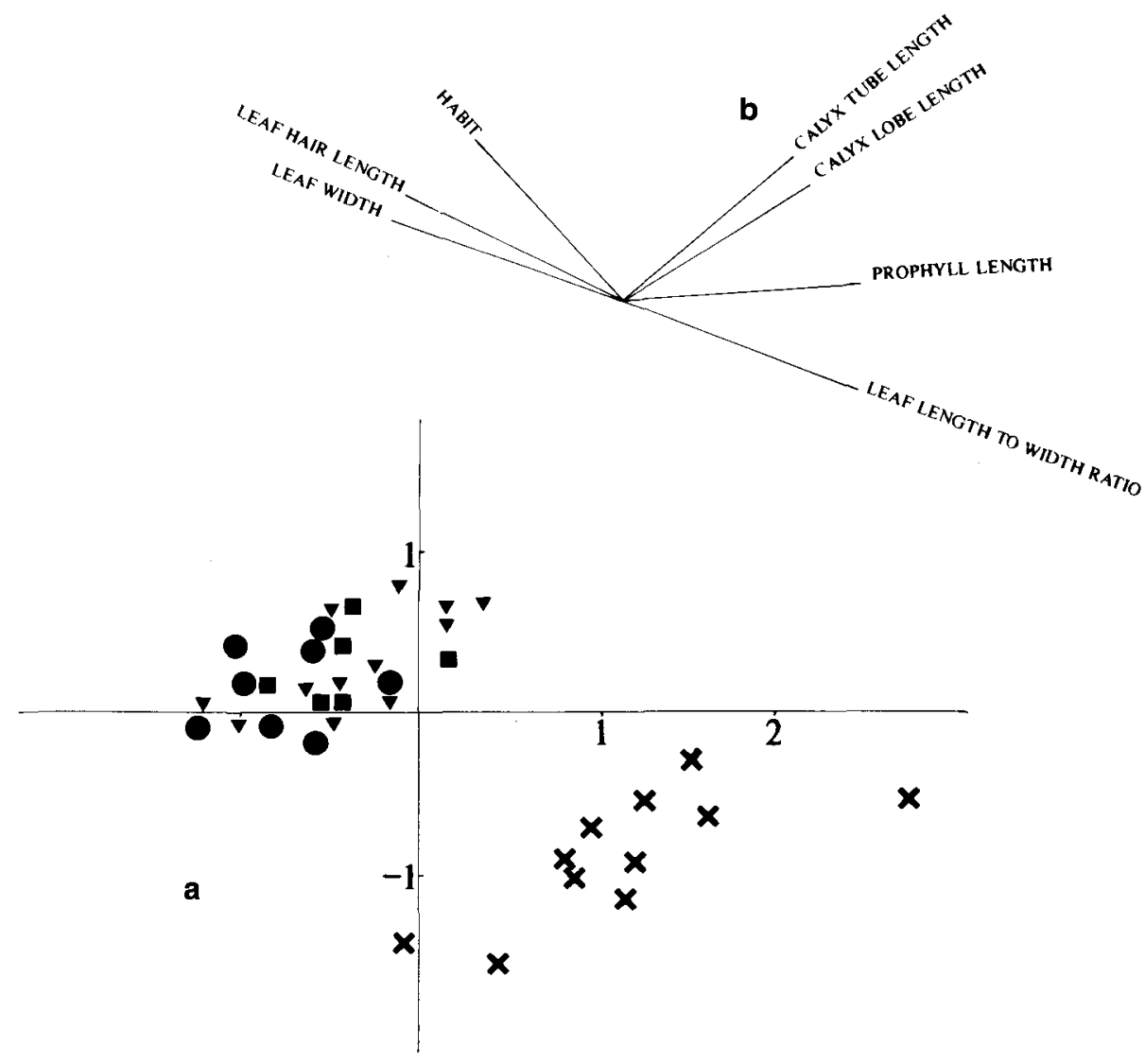

Figure 2. Morphometric analysis of the Westringia fruticosa group; a, Scatter plot of individuals from non-metric Multidimensional Scaling (MDS) ordination in two dimensions using Gower distances. Central Coast collections $(\boldsymbol{\square})$; North Coast $(\bullet)$; South Coast $(\boldsymbol{\nabla})$; Lord Howe Island $(x)$; $\mathbf{b}$, Vectors showing direction of maximum linear correlation between each of the seven characters and the MDS ordination space. 
However, the habit of $W$. viminalis shows less variation since all populations are influenced by similar environmental conditions. It occurs at higher altitudes (usually $450-600 \mathrm{~m}$, rarely as low as $100 \mathrm{~m}$, versus $5-50 \mathrm{~m}$ (rarely to $150 \mathrm{~m}$ ) for $W$. fruticosa). It is considered that the increased precipitation at these higher altitudes reduces the effects of any salt-laden winds. The habitat of $W$. fruticosa is usually different to that of $W$. viminalis. The former species characteristically occurs in open rocky areas, commonly associated with Lomandra longifolia, often bordering coastal woodlands with Banksia integrifolia and Leptospermum laevigatum, whereas W. viminalis always occurs in closed low shrublands (narrow sclerophyll scrub formation, MelaleucaCassinia alliance, sensu Pickard 1983).

Westringia viminalis has narrower leaves than $W$. fruticosa (leaf width: $r=0.609$, $V=0.565$; leaf length to width ratio: $\mathrm{r}=0.815, V=0.696)$. The leaves of $W$. viminalis are (1.6-)2.2-3(-5) mm wide, whereas those of $W$. fruticosa are (2.6-)3.5-4(-5) mm, with the length to width ratio of 5-7.2(-11.7) and (3-)4-5(-6.3), respectively. Seedling, juvenile and shade leaves of both species are broader than the adult foliage. Since juvenile and shade leaves sometimes persist on plants that occur in more sheltered parts of the habitat, it is sometimes difficult to distinguish these species using herbarium material.

The prophylls (prophyll length: $\mathrm{r}=0.816 ; V=0.631$ ) of $W$. viminalis are longer than those of $W$. fruticosa [(2.5-)3-4.3(-5) mm long and (1.5-)2-3 mm long, respectively]. As mentioned above, the apical region of the prophylls of $W$. viminalis is often damaged, such that the prophyll may appear shorter than its true undamaged length.

In $W$. viminalis the hairs of the abaxial leaf surface (leaf hair length: $r=0.815$, $V=0.801)$ are shorter than those of $W$. fruticosa $[0.1-0.2(-0.3) \mathrm{mm}$ long and (0.2-)0.3-

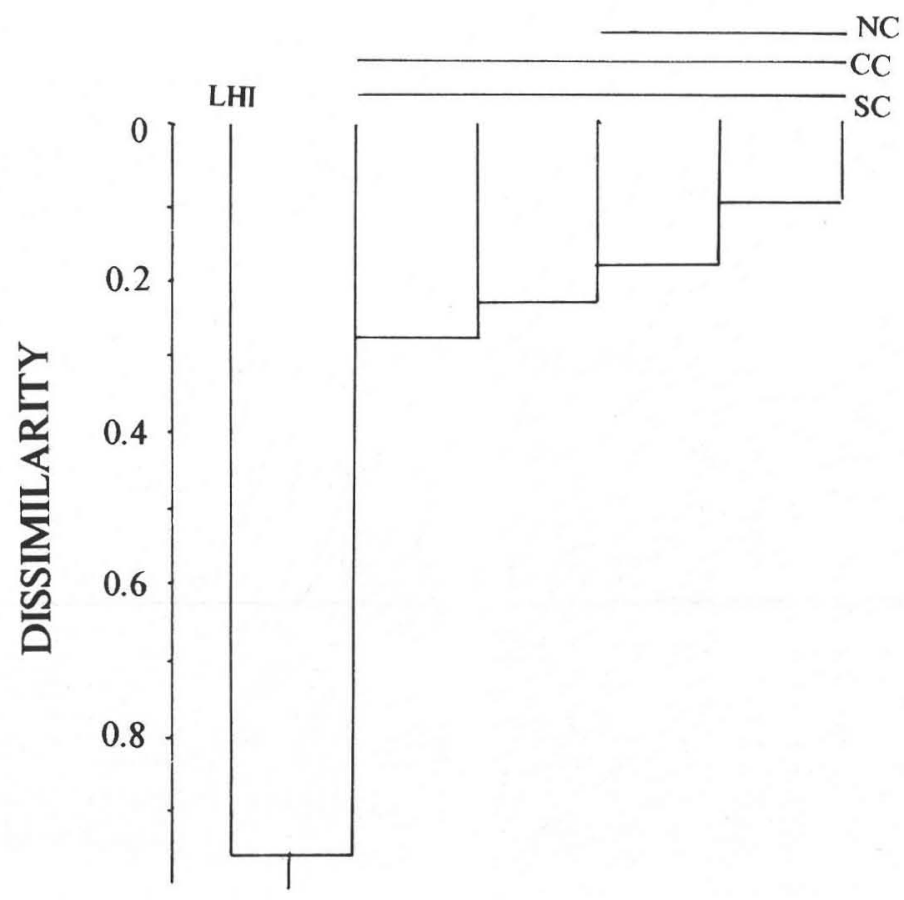

Figure 3. Cluster analysis of morphometric variation in the Westringia fruticosa group. $\mathrm{LHI}=$ Lord Howe Island collections; NC=North Coast; $\mathrm{CC}=$ Central Coast; $\mathrm{SC}=$ South Coast. 
0.4(-0.5) mm long, respectively]. Both species have appressed antrorse leaf-hairs and both are densely hairy.

The SEM survey of the leaf indumentum provided additional support for the recognition of $W$. viminalis as a distinct species. It was found that the indumentum of $W$. viminalis had a hair density of $300-500$ hairs $/ \mathrm{mm}^{2}$ (Figure $4 \mathrm{a}$ ), whereas that of W. fruticosa was $100-150$ hairs $/ \mathrm{mm}^{2}$ (Figure $4 \mathrm{~b}$ ). Furthermore, the hairs of $W$. fruticosa are frequently twisted, whereas those of $W$. viminalis are rarely or only slightly twisted.

The calyx characters proved not to be taxonomically useful in distinguishing between the two species (calyx lobe: $V=0.113$; calyx tube: $V=0.254$; graphically presented in Figure $2 \mathrm{~b}$ ). However, these characters provided more information about the withinspecies variation (calyx lobe: $r=0.630$; calyx tube: $r=0.898$ ).

Field studies of the mainland populations revealed that the high level of withinpopulation variation may be explained by the effects of microclimatic variation at any one site. Plants that occur in rocky areas are exposed to considerable desiccation from harsh sun and strong salt-laden winds. This desiccating effect is compounded by
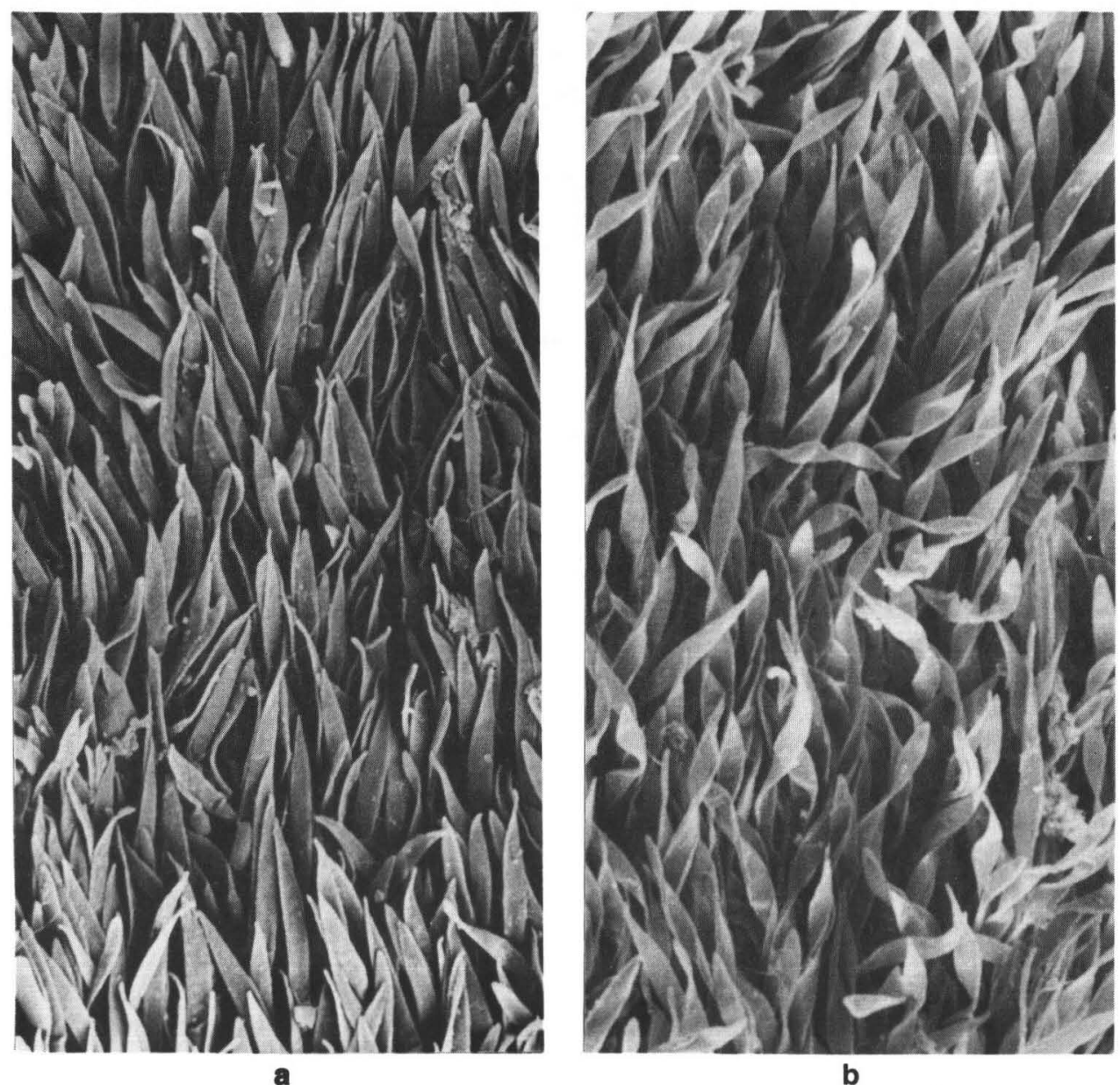

Figure 4. a, Scanning electron micrograph of hairs on abaxial leaf surface of Westringia viminalis; b, scanning electron micrograph of hairs on abaxial leaf surface of Westringia fruticosa. Scale: $1 \mathrm{~mm}=6 \mu \mathrm{m}$ 
occurring in shallow skeletal soils that retain relatively little moisture. The sparse, usually short vegetation provides little protection. The slightly more sheltered sites occur further from the cliff edges, bordering coastal shrubland and low woodland communities. These latter sites sometimes occur on deeper sandy soils overlying sandstone. Of the characters examined, the following are most readily modified by microclimatic differences: habit, internode length, leaf size and leaf colour. Those plants in the more exposed areas are salt-pruned and semi-prostrate, having lighter green leaves, shorter internodes, and narrower leaves with margins strongly recurved, whereas plants occurring in the less exposed sites are taller and upright, having darker leaves, longer internodes, and broader leaves with margins less recurved. Juvenile leaves frequently persist on plants of these more sheltered sites. The hair length and density of the indumentum appeared to be unaffected by changes in the microclimate.

\section{Taxonomy}

Westringia viminalis Conn $\mathcal{E}$ Tozer, sp. nov.

TYPE: LORD Howe ISLAND: c. $200 \mathrm{~m} \mathrm{~S}$ (above) Eddies Cave turnoff, on track to Mt Gower summit, Conn 3573 \& Hutton, 28 February 1992 (holo NSW 253766; iso K, MEL 1610304).

Frutices $0.5-1 \mathrm{~m}$ alti. Rami et ramuli subteretes usque subquadrangulares, moderate usque dense tomentosi, glabrescentes. Folia verticillata quadra; petiolus $0.5-3 \mathrm{~mm}$ longus; lamina anguste elliptica usque anguste obovata vel linearis, $10-18(-21) \mathrm{mm}$ longa, 1-2.5(-3.5) $\mathrm{mm}$ lata, basi acuta usque attenuata, margine integro et recurvo, apice subacuto usque rotundato. Pedicellus floris $0.5-1(-2) \mathrm{mm}$ longus, moderate usque dense tomentosus; prophyllis lineari-ellipticis usque lineari-obovatis, $2.5-4 \mathrm{~mm}$ longis, $0.2-0.3 \mathrm{~mm}$ latis, moderate usque dense tomentosis. Calyx viridis, pilis albis; tubus 3.5-4.5(-5) mm longus; lobi plus minusve deltoidei, $2-3(-3.2)$ longi, $1-1.5 \mathrm{~mm}$ lati, intra moderate usque sparse tomentosi, apice anguste obtuso. Corolla 13-15 mm longa, alba, extra in partibus distalibus sparsim usque moderate tomentosa, intra in faux dense tomentosa; tubus $6.5-7 \mathrm{~mm}$ longus; lobus abaxiali-medianus oblongus usque ovatus, $2.9-3.9 \mathrm{~mm}$ longus, $4.5-6 \mathrm{~mm}$ latus; lobi laterales oblongi usque leviter obovati, 5.5-6 mm longi, $4 \mathrm{~mm}$ lati; par loborum adaxiali-medianorum late oblongum, 3.2-3.5 mm longum, 6-8 mm latum. Androecium in ore corollae insertum; filamenta staminum $3.2-3.5 \mathrm{~mm}$ longa, antherae $1-1.3 \mathrm{~mm}$ longae; filamenta staminodiorum 2.5-3 mm longa; lobi staminodiorum $0.8-1 \mathrm{~mm}$ longi. Pistillum 9-10 $\mathrm{mm}$ longum; ovarium $0.4-0.6 \mathrm{~mm}$ longum; stylus $8-8.5 \mathrm{~mm}$ longus, tomentosus; stigma circa 0.4 $\mathrm{mm}$ longa. Mericarpia 1.6-2.2 mm longa.

Weak, openly branched shrub, 0.5-1 m high. Branches subterete to subquadrangular, moderately to densely hairy [80-200 hairs $/ \mathrm{mm} 2$ ], becoming glabrous on older stems; hairs \pm appressed, simple, antrorse, $0.2-0.4 \mathrm{~mm}$ long. Leaves in whorls of 4 (rarely 3 ), usually only persisting at ends of branches; petiole $0.5-3 \mathrm{~mm}$ long; lamina narrowly elliptic to obovate or linear, $10-18(-21) \mathrm{mm}$ long, 1-2.5(-3.5) $\mathrm{mm}$ wide (length to width ratio 5-9(-11); length of maximum width from base to total lamina length ratio $0.5-0.7)$; abaxial surface very densely hairy $\left(300-500\right.$ hairs $\left./ \mathrm{mm}^{2}\right)$, with hairs $0.1-0.2$ $(-0.3) \mathrm{mm}$ long, longer hairs along midrib and basally; adaxial surface sparsely to densely hairy, with only the base of hairs persisting on mature leaves; base acute to attenuate; margin entire and recurved; apex subacute to rounded; venation not visible, midrib raised on abaxial surface. Inflorescence a frondose racemiform conflorescence, confined to distal nodes; uniflorescence monadic; pedicel $0.5-1(-2) \mathrm{mm}$, 
moderately to densely hairy; prophylls inserted near base of calyx (ratio of anthopodium length to $a_{1}$ axis length c. 0.1 ), linear-elliptic to linear-obovate, $2.5-4 \mathrm{~mm}$ long, $0.2-0.3 \mathrm{~mm}$ wide (length to width ratio 10-13), moderately to densely hairy; base attenuate; margin entire; apex obtuse. Calyx green, appearing white because densely covered with white hairs, mid-vein and lateral veins of each sepal raised, hence tube ridged; outer surface densely hairy; tube 3.5-4.5(-5) $\mathrm{mm}$ long, inner surface glabrous, except moderately hairy near base of lobes; lobes triangular to broadly triangular, 2-3(-3.2) $\mathrm{mm}$ long, 1-1.5 $\mathrm{mm}$ wide (length to width ratio 1.8-2.5) [calyx lobe to tube ratio $0.5-0.7(-0.8)$ ]; margin recurved; glands sometimes present; apex narrowly obtuse; inner surface moderately hairy basally, sparsely hairy distally; hairs $0.1-0.2$ $\mathrm{mm}$ long, antrorse. Corolla 13-15 mm long, white, with orange to brown dots medially on abaxial surface of tube and mouth, or dots absent; outer surface glabrous basally, sparsely to moderately hairy on distal part of tube, densely hairy on lobes, with hairs erect to subappressed and antrorse (0.1-0.2 $\mathrm{mm}$ long); inner surface densely hairy in throat, sparsely to moderately hairy on basal part of lobes, lobes often glabrous distally, with hairs \pm erect and spreading (0.1-0.3 mm long); tube $6.5-7 \mathrm{~mm}$ long, tubular basally, funnel-shaped distally, with mouth c. $2.5 \mathrm{~mm}$ diameter; abaxial median lobe \pm oblong to ovate, $2.9-4 \mathrm{~mm}$ long, $4.5-6 \mathrm{~mm}$ wide (length to width ratio 1-1.2), apex rounded, irregular and bilobed (sinus c. $1 \mathrm{~mm}$ long); lateral lobes oblong to slightly obovate, 5.5-6 $\mathrm{mm}$ long, c. $4 \mathrm{~mm}$ wide (length to width ratio 1.3-1.5), apex rounded and \pm irregular; adaxial median lobe-pair 7.2-8.1 mm long, 6-8 mm wide (length to width ratio $0.9-1.2$ ), bilobed (sinus $3.5-6 \mathrm{~mm}$ long), each half of lobe-pair broadly ovate (length to width ratio c. 1.2) and each with apex rounded and \pm irregular. Androecium inserted in corolla mouth. Staminal filaments $3.2-3.5 \mathrm{~mm}$ long, glabrous or with an occasional hair near the base; anthers $1-1.3 \mathrm{~mm}$ long, basal acumen absent. Staminodal filaments $2.5-3 \mathrm{~mm}$ long, glabrous; staminodal lobes $0.8-1$ $\mathrm{mm}$ long. Disc cylindrical, c. $0.4 \mathrm{~mm}$ high. Pistil $9-10 \mathrm{~mm}$ long; ovary $0.4-0.6 \mathrm{~mm}$ long; style $8-8.5 \mathrm{~mm}$ long, sparsely hairy; stigma lobes c. $0.4 \mathrm{~mm}$ long. Mericarps 1.6-2.2 mm long, distally c. $0.4 \mathrm{~mm}$ extended beyond base of style; seeds flattened, narrowly obovate in outline, $1.5-1.8 \mathrm{~mm}$ long.

Distribution: Endemic to Lord Howe Island (Figure 1b).

Habitat: Occurs in stunted shrubland co-dominated by Metrosideros nervulosa, Cassinia tenuifolia and Olearia ballii, on steep mountain slopes in shallow basaltderived soils. In some localities, it is locally common and hence one of the codominant species of the vegetation, whereas in other localities, it is rare with only a few plants present.

AfFinITIES: The affinities of this species appear to be with $W$. fruticosa. The distinguishing features are discussed above.

ETYMOLOGY: The specific epithet refers to the relatively weak flexible branching of this species.

Conservation status: Although this new species is only known from Lord Howe Island, it is locally frequent on Mt Lidgbird and Mt Gower. However, its distribution is very restricted (geographic range less than $100 \mathrm{~km}$ ) and although not considered endangered or vulnerable, it must be considered rare. The World Heritage listing for the island ensures adequate protection for the known populations. Risk code $=2 \mathrm{RCa}$ (sensu Briggs \& Leigh 1988).

OTHER SPECIMENS EXAMINED: refer appendix 1. 


\section{Acknowledgements}

Mr Peter Green (K) prompted us to undertake a detailed study of the Westringia fruticosa group; a task that we had been avoiding. Mr Ian Hutton (Coffs Harbour, N.S.W.) willingly shared his extensive knowledge of the Lord Howe Island flora, together with his accurate observations of the Westringia populations on that island. Mr Mark Tozer assisted in the collection of the north and south coast New South Wales material. Dr Michael Crisp (Australian National University, Canberra) provided useful comments on the manuscript. Ms Judith Scott (NSW) willingly offered assistance to overcome technical computing problems. The valuable discussions we had with her have added greatly to this study. This study was in part supported by an Australian Biological Resources Study Grant.

\section{References}

Belbin, L. (1987) PATN Pattern Analysis Package. Users, Examples, Command and Reference Manuals. (CSIRO Division of Wildlife \& Ecology: Canberra).

Belbin, L. (1989) PATN Pattern Analysis Package. Users and Technical Reference Manuals. (CSIRO Division of Wildlife \& Ecology: Canberra).

Bentham, G. (1870) Labiatae. Pp 70-137 in Flora Australiensis, vol. 5 (Reeve: London).

Boivin, B. (1949) Westringia, an Australian genus of Labiatae. Proc. Roy. Soc. Queensland 60: 99-110.

Briggs, J.D. \& Leigh, J.H. (1988) Rare or Threatened Australian Plants. 1988 Revised Edition. Austral. Natl Parks \& Wildlife Special Publication 14: Canberra.

Conn, B.J. (1988) The Westringia dampieri-W. eremicola-W. rigida complex (Labiatae). Nuytsia 6(3): 335-349.

Holmgren, P.K., Holmgren, N.H. \& Barnett, L.C. (1990) Index herbariorum. Part 1. The herbaria of the world, edn 8. Regnum Veg. 120.

Oliver, W.R.B. (1916) Vegetation and flora of Lord Howe Island. Trans. \& Proc. New Zealand Inst. 49: 94-161.

Pickard, J. (1983) Vegetation of Lord Howe Island. Cunninghamia 1(2): 133-266.

Rodd, A.N. (1974) Checklist of angiosperms. Appendix B, pp. 21-25, in Recher, H.F. \& Clark, S.S. (eds), Environmental survey of Lord Howe Island (Government Printer: Sydney).

Rodd, A.N. \& Pickard, J. (1983) Census of vascular flora of Lord Howe Island. Cunninghamia 1(2): $269-280$.

\section{Appendix 1. Specimens used in PATN analysis}

Lord Howe Island - Westringia viminalis

W side of Mt Eliza, Beauglehole 5617, 22 Nov 1962 (NSW 248029); Boat Harbour Track, Beauglehole 5999, 16 Sep 1963 (NSW 248028). Mt Lidgbird area: NE flank of Mt Lidgbird, Balgooy 1074, 22 Jul 1965 (NSW 248026); SE slopes of Mt Lidgbird, above the Saddle between Mt Gower \& Mt Lidgbird, Conn 3580 \& Hutton, 29 Feb 1992 (NSW 253366); Goat House, Green 1683, 16 Nov 1963 (NSW 248017); Goat House, Pickard per Rodd 1325, 11 Sep 1970 (NSW); Mt Lidgbird, Rodd 1824, 29 Mar 1971 (NSW 248033); vicinity of the Goat House, Rodd 1859, 23 Aug 1971 (NSW 248038). Mt Gower area: c. $200 \mathrm{~m} \mathrm{~S}$ (above) Eddies Cave turnoff, on track to Mt Gower summit, Conn 3573 \& Hutton, 28 Feb 1992 (NSW 253766, K, MEL); N end Little Slope, Pickard 2757, 9 Dec 1975 (NSW 248041); Eddies Cave, Pickard 3596, 12 Jul 1978 (NSW 248040). No locality cited: McComish s.n. [?143], Jan 1937 (NSW 248030); McComish s.n. [?143], Oct 1938 (NSW 248032). 
New South Wales - Westringia fruticosa

North Coast: Point Boomerang, Tozer 1005a-1005b \& Tozer, 24 Nov 1991 (NSW 246972, NSW 247899); Cape Hawke, Tozer 1006 \& Tozer, 24 Nov 1991 (NSW 246987); Red Head, Tozer 1008 \& Tozer, 25 Nov 1991 (MEL, NSW 246994); Seal Rocks, Tozer 1009-1012 \& Tozer, 25 Nov 1991 (NSW 246995-246998). Central Coast: S headland of East Beach, Kiama, Tozer 1014-1015, 17 Dec 1991 (NSW 248452 \& NSW 248453); Blowhole Point, Kiama Tozer 1016-1017, 17 Dec 1991 (NSW 248454 \& NSW 248455); S headland of Thirroul Beach, Tozer 1018, 17 Dec 1991 (NSW 248456); N headland of Austinmer Beach, Tozer 1019, 17 Dec 1991 (NSW 251152); N headland of Stanwell Park, Tozer 1020, 17 Dec 1991 (NSW 251154); coastal walk from Bundeena, Tozer 1024, D'Orazio \& Doust, 17 Mar 1992 (NSW 252509); Gairie Beach, Tozer 1025, D'Orazio \& Doust, 17 Mar 1992 (NSW 253264). South Coast: Headland of Mossy Point, Betteridge s.n., 8 Jun 1974 (NSW 245838); Eden, Boorman s.n., 29 Dec 1916 (NSW 245852); Tathra Headland, Foreman 861, 4 May 1985 (MEL, NSW 245846); Conjola, Heron s.n., Feb 1899 (NSW 245824); Cape Dromedary, Phillips s.n., 8 Mar 1961 (NSW 245843); Montague Island, Rodway 733, 4 Apr 1932 (NSW 245841); Green Cape, Tozer 1030 \& Tozer, 29 Apr 1992 (NSW 254424); Cape Dromedary, Tozer 1032 \& Tozer, 30 Apr 1992 (NSW 254431); Beagle Bay, Tozer 1035 \& Tozer, 30 Mar 1992 (NSW 154444); Twofold Bay, Wakefield 4631, 1 Oct 1950 (MEL, NSW 245853).

Manuscript received 26 June 1992

Manuscript accepted 10 February 1993 